\title{
Imaging underwater neotectonic structures in the Amazonian lowland
}

\author{
Dilce F. Rossetti ${ }^{1}$ \\ ${ }^{1}$ Instituto Nacional de Pesquisas Espaciais - INPE \\ Caixa Postal 515 - 12227-010 - São José dos Campos - SP, Brasil \\ \{rossetti@dsr.inpe.br \}
}

\begin{abstract}
Previous documentation has proposed tectonic activity from the Neogene to Holocene as one important control on the drainage development in the Amazonian lowland. However, recording tectonic structures in this region has been challenging due to environmental difficulties including the low topography and dense vegetation cover that do not favor natural exposures. For this reason, the role of tectonics in determining river dynamics, morphology, and sediment deposition in Amazonia has been suggested with caution. Despite limitations, morphostructural lineaments have provided useful information to support fault reactivation in several areas of the Amazonian lowland. However, further documentation is required to map the faults and describe their geometry. This approach is essential to better understand the geotectonic model of this region. In this work, analyses of high-resolution optical imagery of three Amazonian shallow water lakes provided exceptional views of an abundance of linear features on the beds of these lakes. Although based on indirect evidence from remote sensing data, the quality of the images allowed the geometry of these underwater features to be characterized in detail. The most striking are sets of NE-SW lineaments that frequently intercept NW-SE trending lineaments with offsets of up to $500 \mathrm{~m}$ in the horizontal plane. These characteristics support dextral faults with strike-slip rates in the study areas. The faults display trends compatible with the geotectonic model proposed for the Brazilian Amazonia region. They also control the morphology of lakes and rivers, as indicated by the fact that they parallel and/or continue into straight lineaments that define lake margins and river courses, including the courses of large rivers, such as the Solimões and Amazonas Rivers. Available radiocarbon ages of deposits from the lake bed sediments and from related floodplain deposits are consistent with the proposal of faulting during the latest Holocene, even only a few hundred years ago.
\end{abstract}

Keywords: Amazonia lowland, neotectonics, remote sensing, morphostructural lineaments, shallow lakes.

\section{Introduction}

Morphostructural analyses of drainage basins, particularly those based on remote sensing data, have been the only source of information for inferring tectonic structures in several regions of the Amazonian lowland. Efforts to relate morphostructural data derived from drainage networks to tectonic structures have often been criticized (e.g. Jackson and White, 1989; Leopold and Wolman, 1957; Wang and Ni, 2002). This is particularly an issue in the Brazilian Amazonian lowland, where the physical aspects and geometries of the inferred faults have not been characterized, with their interpretation being based largely on morphostructural criteria. With a few exceptions where geophysical data have been applied in combination with morphostructural analysis for demonstrating fault nature (e.g. Rossetti et al., 2012), morphostructural lienaments have yet to be related to structures existing in the subsurface of the Brazilian Amazonian lowland.

Before novel geological data become available, it is pertinent to use remote sensing products, chiefly those of high resolution freely available on virtual globes, in order to analyze further the geotectonic model of the Amazonian lowland. Such an approach can serve the purposes of providing data to plan future research on tectonic structures in the field.

This work presents descriptions of morphostructural features from three areas of the Amazonian lowland that have geometric characteristics compatible with tectonic structures, mainly faults. This interpretation was possible with the analysis of high resolution optical images available from Google Earth, which allowed imaging either shallow water lakes or lakes with eventual subaerial exposure during dry periods. This 
technology provided a flawless view of structures developed on the lake bottom sediment surface. The exceptional view of these underwater structures and their correlation with morphostructural lineaments over land areas constitute perhaps the first convincing evidence of faults and their geometry in lowland areas of the Amazon basin.

\section{Study Area and Geological Context}

Three locations (Figura 1) were selected for this study according to the availability of image. These include the following lakes: (i) Aramanaí-Itarim, north of the town of Santarém; (ii) Canaçari between the towns of Urucuritiba and Silves; and (iii) Acará northeast of the town of Coari. These are all shallow lakes of the Amazonian lowland located in the intracratonic Amazonas Basin. Several tectonic faults have been recognized in this basin, as well as in the adjacent (westward) Solimões Basin, which affected sedimentary successions up to the Holocene (e.g., Sternberg, 1950; Franzinelli and Latrubesse, 1993; Souza-Filho et al., 1999; Costa et al., 2001; Latrubesse and Franzinelli, 2002; Bezerra 2003; Silva, 2005). These authors have agreed on the geotectonic model for this region, which mostly includes normal and/or transcurrent NW-SE and NE-SW trending faults and subordinate E-W, ENE-WSW and N-S trending faults.

\section{Materials and Methods}

The features described here derive from direct observation of high resolution images of the Google Earth's free catalog (accessed at http://www.google.com/earth/index.html). This is a multisource data set provided in KML format and stored on a spherical Earth model using geographic coordinates of the World Geodetic System of 1984 (WGS84) datum. The data for Lake Aramanaí-Itarim included: (i) TM and TM+ Landsat images acquired on 20 August 2010 and 12 August 2013; (ii) $10 \mathrm{~m}$-resolution panchromatic SPOT-4 images acquired on 20 July, 17 August and 12 September 2011; and (iii) Digital Globe image-Catalog ID 1010010001606702 acquired on 29 October 2002. The information on Lake Canaçari was based on: (i) Landsat images from 3 August 2013; and (ii) $10 \mathrm{~m}$-resolution panchromatic SPOT 4 images acquired on October $2^{\text {nd }}, 2011$. The images used for Lake Acará included: (i) Landsat image from 28 October 2001; (ii) $10 \mathrm{~m}$-resolution panchromatic SPOT-4 images acquired on 10 June 2011; and (iii) a Digital Globe image-Catalog ID 1010010005B7DF01. These images were ready for use, and required only simple adjustments to change the saturation, as well as to improve the brightness, contrast and intensity.

\section{Description of Linear Features}

The three lakes studied display numerous linear structures in their bottom sediments that can be analyzed in great detail due to their exceptionally good preservation. The maintenance of the sediment surface below the water column seems to have been crucial to preserve the primary morphology of these structures. As described hereinafter, the underwater features are in continuity with morphostructural lineaments over land areas. However, they can be analyzed in greater detail in the underwater environment than in the terrestrial one. This is probably due the fact that the shallow water column acted as a protection from any significant interference of pedogenesis, vegetation growth or relief dissection that could obliterate these features to a certain degree, as opposed to those exposed in the terrestrial environment. 

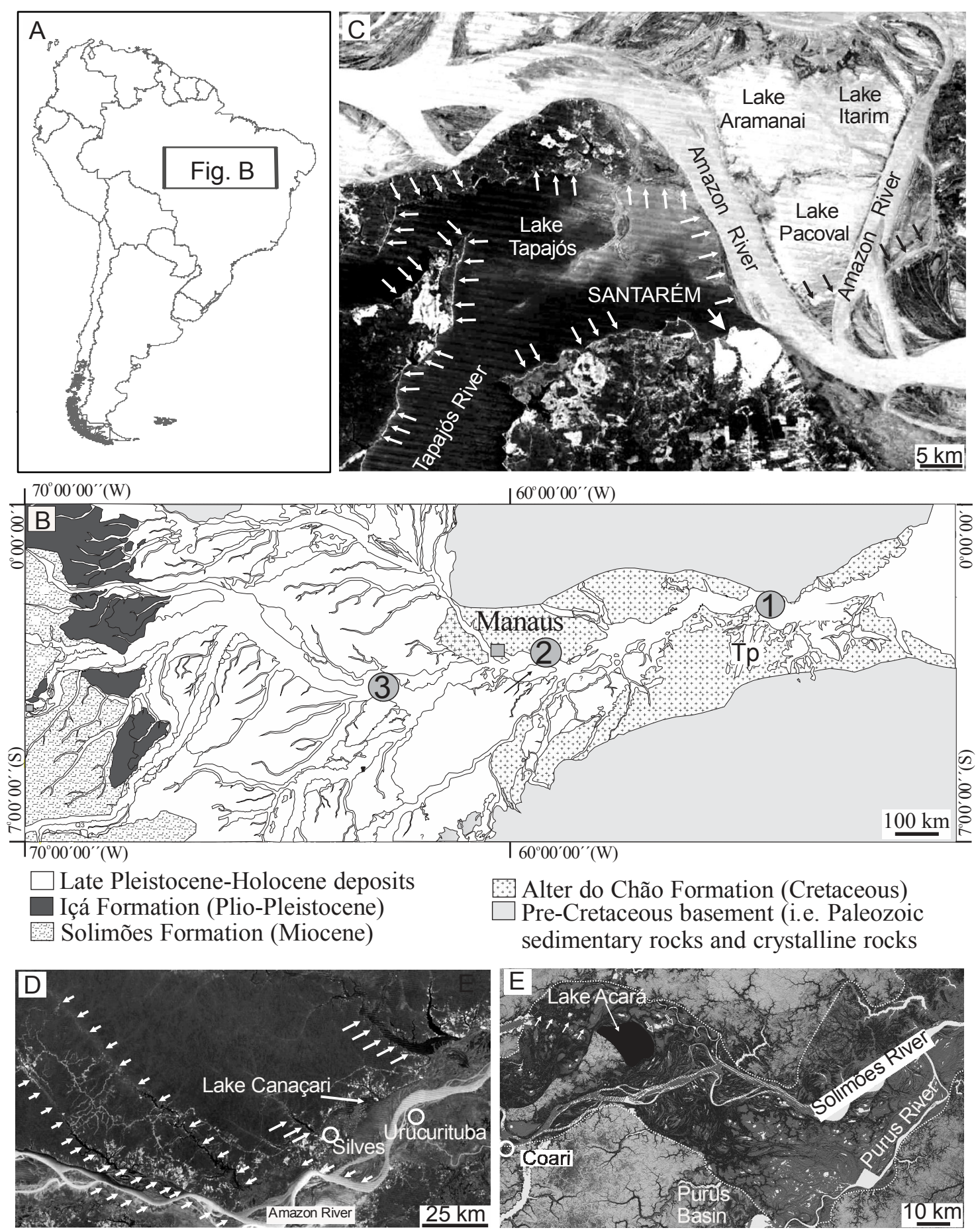

$160^{\circ} 00^{\prime} 00^{\prime \prime}(\mathrm{W})$

Figure 1. Location and geological context of the study areas in the Amazonian lowland. A-B) Location (A) and geological context modified from Rossetti et al. (2005) (B) of the three studied lakes and of the main river tributaries that form the Amazonas basin, where: 1 = Lake Aramanaí-Itarim; 2 = Lake Canaçari; and 3 = Lake Acará. C) Location of Lake Aramanaí-Itarim to the east of Lake Tapajós, D) Location of Lake Canaçari in a region containing several NW-SE trending fluvial rias (long arrows) that parallel lineaments in physical continuity with straight stair-shaped segments of the Amazon River (short arrows). E) Location of Lake Acará, a half moon-shaped lake connected to the Solimões River through a narrow channel (white open arrows). 
The linear features from Lake Aramanaí-Itarim (Figs. 2A-C) consist of a series of either single or double, parallel and straight segments up to $2.2 \mathrm{~km}$ in length. Lineaments trending in the NW-SE direction were displaced by a dominant set of straight to slightly curved segments oriented in the main NE-SW direction, with offsets of up to $500 \mathrm{~m}$ (Figs. 2B,C and 3A). It is remarkable that the NW-SE lineaments extend southeastward into a straight subaqueous and then subaerial channel with a welldeveloped pair of vegetated, marginal levees that make the boundary between lakes Aramanaí and Itarim (Fig. 2A). To the south, Lake Aramanaí is separated from Lake Pacoval by another channel with similar levees and straight segments trending in the main NW-SE direction (see black arrows in the lower part of Fig. 2A). A striking point of interest is that the lakes's margins are defined by several straight segments (white arrows in Fig. 2A) oriented in the NNW-SSE direction, paralleling the underwater NW-SE or NE-SW linear structures observed in this area. The parallelism of all these features with the two arms of the Amazon River at this locality is remarkable, and it imposes on a triangular shape for the Aramanaí-Itarim-Pacoval lake system (Fig. 1C). Another point of interest is the occurrence of these lakes immediately to the east of Lake Tapajós. This lake has a rectangular-shaped morphology bounded by a series of sharp and orthogonal to nearly-orthogonal straight lineaments of variable directions at the mouth of the Tapajós River (white arrows in Fig. 1C). Interestingly, some of these lineaments extend northeastward beyond this lake's margin (black arrows in Fig. 1C).

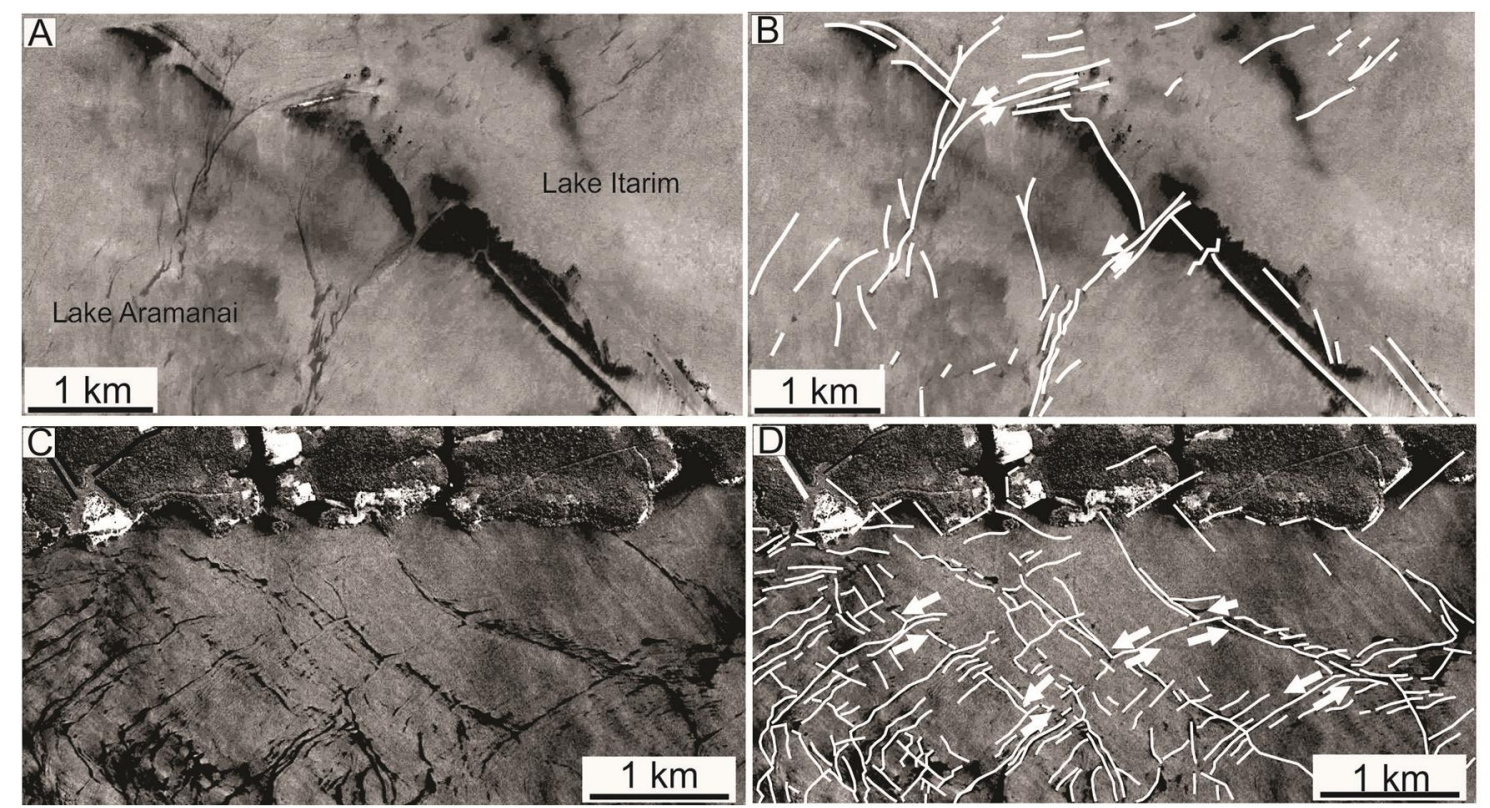

Figura 2. Linear features of Lake Aramanaí-Itarim (A,B) and Lake Canaçari (C,D), which are related to NW-SE faults laterally displaced by NE-SW strike-slip faults. Lines in figures $\mathrm{B}$ and $\mathrm{C}$ indicate the linear features and the arrows show the lateral fault offsets.

A number of linear features are observed underwater in Lake Canaçari. Most of them are straight, although some are slightly curved. The longest lineaments are only about $1 \mathrm{~km}$ long, but they align with other linear segments in order to define major lineament sets up to $5 \mathrm{~km}$ in length. As in Lake Aramanaí-Itarim, there are two main groups of lineaments in Lake Canaçari that preferentially have NE-SW and NW-SE trends (Figs. 3B and 4A-C). Where these intersect each other, they form orthogonal to nearly-orthogonal angles. The NW-SE lineaments may also display offsets of a few tens of meters. A prominent characteristic of the lineaments in this area is their 
parallelism to the straight lineaments at the lake's margin (Fig. 4D-E). In addition, the underwater lineaments are in perfect continuity with straight lineaments that define the lake's margin (Fig. 4F-G). Lake Canaçari occurs in a region with several NW-SE trending fluvial rias (see sets of long white arrows in Fig. 4D) that parallel regional lineaments, some of them in continuity with straight stair-shaped segments of the Amazon River (see sets of short white arrows in Fig. 1D).

The third example of linear features derives from Lake Acará. This lake occurs in the center of a major paleomeander belt that records a previous course of the Solimões River (Fig. 1E). It has a half-moon shape bounded by an anomalously straight lineament in its southwest margin; this lineament can be followed northwestward at least $15 \mathrm{~km}$ beyond the lake's margin (see white solid arrows in Fig. 1E). Lake Acará eventually dries out during dry periods, providing excellent exposure of its bottom where a complex of channels developed (Fig. 5). This complex typically consists of a network of either slightly sinuous or, more commonly, meandering channels, although straight channels can be observed locally (Fig. 5A-B). Channels are usually narrow (i.e., $<10 \mathrm{~m}$ wide). However, a channel up to $50 \mathrm{~m}$ in width cuts through the lake's bottom, and flows into a drainage system connected to tributaries of the Solimões River (see white open arrows in Fig. 1E and white solid arrows in Fig. 5A). The most interesting feature is that, although sinuous and meandering, all channels run systematically over straight pathways with variable directions (i.e. mainly NNE-SSW, NNW-SSE, NE-SW and NW-SE (Fig. 3C). It is also worth noting the numerous abrupt changes in the channel's courses. These changes frequently result in orthogonal junctions, characterizing rectangular (Fig. 5C) or even square drainage patterns (Fig. 5D). In addition to channels, many ponds appear on the exposed lake bottom, each usually less than $50 \mathrm{~m}$ in diameter (see dark spots in Fig. 4B-D). Most of the ponds are tear- or triangular-shaped, and are either isolated or most commonly interconnected by the lineaments. Sets of ponds can be aligned over these lineaments (Fig. 5E), and triangular ponds may occur where the lineaments form triple junctions (Fig. 5F).

\section{Discussion}

Even though the present study is based only on remote sensing data, the consistency of the morphostructural lineaments documented in the studied lakes is compatible with their attribution to tectonic structures. The parallelism of the numerous NW-SE trending lineaments that are crossed by sets of NE-SW trending lineaments agrees with their attribution to a conjugate fault system. However, the most remarkable evidence of faults in the study area is provided by the frequent displacement of NW-SE lineaments by NE-SW lineaments in the horizontal plane, particularly characteristical of lakes Aramanaí-Itarim and Canaçari. These lateral offsets, which can be followed over a distance of nearly $500 \mathrm{~m}$, imply that the lacustrine deposits were affected by dextral strike-slip fault deformation. NE-SW trending faults are better represented in the study area, followed by NW-SE trending faults. The relationship between these two systems indicates that the NE-SW faults developed after the NW-SE faults.

The fault interpretation for the lineaments described in the studied lake systems is reinforced by the straight, orthogonal to nearly-orthogonal margins of the studied lakes. This interpretation also explains the two straight arms of the Amazon River, which imposed on a triangular shape for the lake system near the Tapajós River mouth, as shown in Fig. 1C. The internal channel at the boundary between lakes Aramanaí and Itarim in this area follows a fault plane, as indicated by its direct continuity into NESW fault segments. Segments of the channel between lakes Aramanaí and Pacoval paralleling NW-SE faults at the lake's margin and bottom are presumably fault- 
controlled. It is noteworthy that this lake system occurs at the mouth of the Tapajós River, where a rectangular lake $20 \mathrm{~km}$ wide and more than $30 \mathrm{~km}$ long was formed (Fig. $1 \mathrm{C})$. It is noteworthy that this lake also displays straight, orthogonal to nearlyorthogonal margins that are compatible with a tectonic control.

The anomalous half-moon shape of Lake Acará, defined by a southwest straight lineament unconfined to this lake's margin, is highly suggestive of a fault or fracture plane. This tectonic interpretation agrees with the fact that: (i) the sinuous and meandering channels from the bottom of this lake systematically run over straight pathways; and (ii) the channels often show abrupt turns that produce orthogonal shapes and even perfect squares. Although the directions of these pathways vary, their main trends within the NE-SW and, less frequently, NW-SE quadrangles are compatible with the main directions of the lineaments recorded in the other studied lakes. Given the proposed tectonic interpretation, it follows that at least some of the numerous tear- or triangular-shaped ponds connected to the lineaments described at the bottom of Lake Acará would record small depressions formed in areas of stress release along the structural lineaments.

The fact that the faults at the lake's bottom parallel straight lineaments from the lake's margins is good evidence that the latter also reflect fault traces. The finding that some faults observed underwater is in perfect continuity with the straight lineaments that define the lake's margin reinforces this interpretation. Such characteristic might constitute a valuable observation to help the recognition of tectonic structures in areas other than lake settings.

The continuity of Lake Canaçari into NW-SE trending fluvial rias is also interesting. This is because such features parallel the main regional lineaments that form straight stair-shaped segments in the Amazon River, as shown in Fig. 1D. Such characteristics, in conjunction with the others discussed here, further supports the view that the drainage system in this region, including fluvial rias, has been controlled by fault activity.

The fault systems recognized in the studied lakes are in agreement with the main tectonic trends recorded in different areas of the Brazilian Amazonia (e.g., Sternberg, 1950; Franzinelli and Latrubesse, 1993; Souza-Filho et al., 1999; Costa et al., 2001; Latrubesse and Franzinelli, 2002; Bezerra 2003; Silva, 2005; Almeida-Filho and Miranda, 2007; Silva et al., 2007).

\section{Conclusions}

The present study leads to the conclusion that high resolution satellite imagery is ideally suited to the mapping of faults in underwater sites of equatorial areas such as the Brazilian Amazonia. The numerous lineaments and associated features preserved at the bottom of the three studied lakes constitute the best yet available evidence of tectonic activity affecting sediment deposition and drainage patterns of the Amazonian lowland in the Holocene. The observation of such features was possible in this tropical environment due to the fact that the lakes have either shallow water column of only a few meters or eventual subaerial exposure of the lakes' bottoms during peaks of dry seasons. Under such conditions, the visualization of morphostructural lineaments was favored due to the protection from subaerial processes, mainly including relief dissection, pedogenesis and vegetation growth. Lineaments from both the bottom and margins of the studied lakes generally follow the main NW-SE and NE-SW trends that coincide with preferential directions of regional fault systems. The numerous offsets of NW-SE lineaments by NE-SW lineaments leave no doubt as to their association with dextral strike-slip tectonic stresses. In this tropical lowland, the morphology of the main 
rivers and of their tributaries is controlled by these faults. The morphostructural analysis presented here can help in improving the geotectonic model for the Amazonian lowland and better understanding the impact of neotectonic activity on the establishment of modern fluvial morphologies associated with the Amazon drainage basin.

\section{Acknowledgements}

This work has the financial support of FAPESP (Project \# 13/50475-5).

\section{References}

ALMEIDA-FILHO, R.; MIRANDA, F.P. Mega capture of the Rio Negro and formation of the Anavilhanas Archipelago, Central Amazônia, Brazil: evidences in an SRTM digital elevation model. Remote Sensing of Environment, v. 110, p. 387-392, 2007.

BEZERRA, P.E.L. Compartimentação morfotectônica do interflúvio Solimões-Negro. PhD Thesis, Universidade Federal do Pará, Brazil. 2003.

FRANZINELLI, E.; LATRUBESSE, E. The use of remote sensing in a neotectonic study in the Amazon Basin. International Quaternary Bulletin, v. 16, p. 10-13, 1993.

JACKSON, J.A.; WHITE, N.J. Normal faulting in the upper continental crust: observations from regions of active extension. Journal of Structural Geology, v. $11,15-36,1989$.

LATRUBESSE, E.M; FRANZINELLI, E. The Holocene alluvial plain of the middle Amazon River, Brazil. Geomorphology, v. 44, p. 241-257, 2002.

LEOPOLD, L.B.; WOLMAN, M.G. River Channel Patterns: Braided, Meandering and Straight. Geological Survey Professional Paper, v. 282B, p. 39-85, 1957.

ROSSETTI, D.F.; TOLEDO, P.M.; GÓES, A.M. New geological framework for Western Amazonia (Brazil) and implications for biogeography and evolution. Quaternary Research, v. 63, p. 78-89, 2005.

ROSSETTI, D.F.; SOUZA, L.S.B.; PRADO, R.L.; ELIS, V.R. Neotectonics in the northern equatorial Brazilian margin. Journal of South American Earth Sciences, v. 37, p. 175-190, 2012.

SILVA, C.L. Análise da tectônica Cenozóica da região de Manaus e adjacências. PhD Thesis, Universidade Federal do Amazonas, Brazil. 2005.

SILVA, C.L.; MORALES, N.; CRÓSTA, A.P.; COSTA, S.S.; JIMÉNEZ-RUEDA, J.R. Analysis of tectonically-controlled fluvial morphology and sedimentar processes of the western Amazon basin: an approach using satellite images and digital elevation model. Anais da Academia Brasileira de Ciências, v. 79, p. 693-711, 2007.

SOUZA-FILHO, P.W.M.; QUADROS, M.L.E.S.; SCANDOLARA, J.E.; SILVA, E.P.; REIS, M.R. Compartimentação morfoestrutural e neotectônica do sistema fluvial Guaporé-Mamoré-Alto Madeira, Rondônia, Brasil. Revista Brasileira de Geociências, v. 29, p. 469-476, 1999.

STERNBERG, H.O. Vales tectônicos na planície amazônica. Revista Brasileira de Geografia 12: 3-26, 1950.

WANG, S.-J.; NI, J.-R. Straight river: its formation and speciality. Journal of Geographical Sciences, v. 12, p. 72-80, 2002. 